\title{
Growth and yield response of camelina sativa to inorganic fertilizers and farmyard manure in hot semi-arid climate of India
}

\begin{abstract}
Camelina [Camelina sativa L. (Crantz)], a potential alternative oilseed crop of family Brassicaceae, has gained renewed interests as a feedstock for biodiesel production. Effect of sulphur $\left(0,10,20\right.$ and $\left.30 \mathrm{~kg} \mathrm{ha}^{-1}\right)$ and farmyard manure (FYM) (20 and 30tons $\mathrm{ha}^{-1}$ ) on plant growth, seed yield and oil content of camelina in degraded land of hot semi-arid climate was studied during the winter season (November to February). Both Sulfur and organic fertilizer neither significantly $(\mathrm{P}<0.05)$ influenced plant growth nor yield attributes nor even seed oil content of camelina. However, addition of $\mathrm{N}$ and $\mathrm{P} 2 \mathrm{O} 5$ exhibited significant $(\mathrm{P}<0.05)$ increase growth and seed yield including seed oil content over control. Maximum seed yield $(72.2 \mathrm{~g} \mathrm{~m}-2)$ was recorded in treatment combination comprising 30 tons FYM, 20kg S, 60kg P2O5 and $100 \mathrm{~kg} \mathrm{~N}$ ha $^{-1}$. Seed oil content, ranged from 29.1 to $32.5 \%$. Quality of seed oil of camelina (grown at the hot semi-arid climate) was also assessed by analyzing the patterns of fatty acids composition. Results indicated that camelina can be successfully cultivated in the degraded land of hot semi-arid zone during the winter season that too in a short growing period. Considerable seed yield and oil content as well as corresponding fatty acid profile of camelina oil reported in this study indicated promising potentials for its suitability for the hot semi-arid regions. However, it would be pertinent to further identify growth and production requirements for the crop in order to strengthen baseline data on its agronomic attributes for ensuring its efficient cultivation on degraded lands of hot semi-arid region.
\end{abstract}

Keywords: camelina, biofuel crops, biodiesel, organic manure, sulfur fertilization
Volume 7 Issue 3 - 2017

\author{
Soumai Kant Joshi, Sharif Ahamada, Lekha \\ Charan Meher, Ankur Agarwal, Mohammed \\ Nasim
}

Defence Institute of Bio-Energy Research, India

Correspondence: Ankur Agarwal, Defence Institute of BioEnergy Research, Goraparao, Haldwani- 263 139, Uttarakhand, India,Tel +9| 5946232800; Fax +9| 59462327I9,

Email ankurdr@rediffmail.com

Received: October 12, 2016 | Published: July 07, 2017

\section{Introduction}

Commonly known as 'false flax' and 'Gold of Pleasure', Camelina sativa (L.) Crantz (Brassicaceae) is believed to be the native of northern Europe, the Mediterranean region and Central Asia. It has gained renewed interest as a biofuel feedstock. ${ }^{1-3}$ Oil content in camelina seeds is reported in the range from 32 to $46 \%{ }^{4}$ Camelina is favoured as an alternative feedstock for biodiesel production due to its low cost in comparison to commodity oils. ${ }^{5}$ Moreover, the fuel properties including cold flow properties, oxidative stability, kinematic viscosity and cetane number of biodiesel made from camelina are similar to those of the soybean-based biodiesel ${ }^{6}$ and canola. ${ }^{3}$ Recently, camelina oil-based jet fuel has been developed and test flights of different passenger aircrafts as well as fighter jets have been successfully conducted. ${ }^{5}$ These facts clearly indicate the suitability of camelina oil for making biofuels. Moreover, because of its unique nutritive properties, camelina meal has been identified as a high-value animal feed. ${ }^{7}$ Thus it holds high economic potential. Such a high economic value of camelina meal has tremendous potential in ensuring camelina biodiesel economically more viable. Growing environments influence quality and quantity of seed and oil yield of oilseed crops. ${ }^{8}$ therefore it is important to develop region-specific production technologies for a newly introduced crop in a particular agro-climatic region. Identification of nutrients requirement is one of the important factors that need to be standardized for such crop. In order to avoid food versus fuel conflict, it is advocated that biofuel crops should be grown on degraded lands, which are generally not suitable for growing other agricultural foods crops as they either cannot grow or exhibit poor growth and low production in such soils. In view of this, and because of its wide adaptability to different climates and soils. ${ }^{9}, 10$ Camelina seems to be a potential biofuel crop. This is particularly important in the Indian context, where degraded lands in the semi-arids are widely available and are more or less underutilized due to unavailability of a suitable low input crop. Camelina seems to be a potential candidate crop for this region being short duration, drought tolerant and low input requiring. Realizing the potential, the crop has already been introduced in India and found successful in central Himalayan region. ${ }^{11}$ Efforts are been made for assessing its adaptability and developing agro-technologies for in semi-arid zones of India. However, fertilization and agronomic requirements of the crop for such agroecological regions need to be standardized for obtaining optimal yields. In general, oilseed crops have a much higher requirement for sulphur for attaining optimum growth and yield vis-à-vis quality and quantity of oil.sPlant use efficiency of nitrogen from fertilizers is inhibited by deficiency of Sulfur. ${ }^{13}$ That may cause increased losses of nitrogen. ${ }^{14}$ Therefore, fertilizers containing Sulfur seem to be effective in camelina nutrition and subsequently in obtaining copious seed and oil yield. In addition to mineral fertilizers, organic fertilizers play a vital role in increasing soil fertility and productivity thereby increasing the yield in sustainable manner. Organic matter supplied in the form of farmyard manure (FYM), green manure or compost to the soil is considered as the most important factor for enhancing crop productivity. ${ }^{15}$ As it positively affects physical, chemical and biological properties of soil. ${ }^{16}$ The objectives of the study were to evaluate the effect of Sulfur and organic fertilizer on plant growth, seed yield and oil content in camelina in the degraded land of hot semi-arid zone of Deccan Plateau, India. 


\section{Materials and methods}

\section{Study site and land preparation}

The present research work was carried out at DIBER Project Site, Chichondi Patil, Ahmednagar, Maharastra, India (18² $58^{\prime} \mathrm{N}$; 7454' E; $708 \mathrm{~m}$ a.s.1.). It is one of the project sites of DIBER, where plantation of Jatropha curcas L. (jatropha) has been established on degraded pasture in hot semi-arid ecosystems of the Deccan Plateau. Mild and dry winters, hot and humid summers and low annual rainfall (300 to $550 \mathrm{~mm}$ ) are the characteristics of the climate of the region. Mean maximum and minimum temperature of the study sites during the study period (November 2011 to February 2012) were 32.4 (ranged from 30.4 to $37.3^{\circ} \mathrm{C}$ ) and $16.8\left(14.2\right.$ to $\left.18.5^{\circ} \mathrm{C}\right)$, respectively. The average monthly relative humidity during this period ranged from 40.2 to $57.7 \%$ (maximum) and 23.1 to $35.9 \%$ (minimum). The soil of the study site was shallow black having low fertility levels $(245.0 \mathrm{~kg}$ $\mathrm{N} \mathrm{ha}^{-1} ; 3.6 \mathrm{~kg} \mathrm{P} \mathrm{ha}^{-1} ; 0.38 \%$ organic carbon). Field experiments were undertaken during November 2011 to February 2012 (winter season) on a land, which was previously used to raise jatropha nursery once each in the year 2010 (February to July) and 2011 (February to August). Prior to growing jatropha nursery, the land (pasture) was occupied by perennial grasses. Also, frequent occurrence of boulders was there on the pasture. Therefore, for raising jatropha nursery for the first time, the land was prepared by carrying out one deep ploughing followed by two shallow ploughing s with a mouldboard plough in December 2009 followed by removal of boulders and grass residues. Thereafter, nursery of jatropha was established twice on the prepared land, i.e. first batch during February to July, 2010 and second one during February to August 2011 and the saplings of each batch were harvested for transplantation in the field in the respective rainy seasons of each year. Hence, after uprooting the second batch of jatropha nursery in August 2011, the nursery space was left for two months without any intercultural practices and interventions. In October 2011, one deep ploughing was carried out on the same field and experimental beds (plots) were prepared to carry out the present research work.

\section{Plant material}

Small quantity of nucleus seeds of camelina cv. Calena (EC 643910) was obtained from Austria through the National Bureau of Plant Genetic Resources (NBPGR), New Delhi by DIBER. These seeds were successfully multiplied at DIBER Field Station, Pithoragarh, Uttarakhand, India $\left(1700 \mathrm{~m}\right.$ a.m.s.1.). ${ }^{11}$ Seeds, thus multiplied, were brought to DIBER Project Site, Chichondi Patil, Ahmednagar (Maharashtra), the present study site, and stored at room temperature in muslin cloth bag until utilized for experimental work in the present study.

\section{Experimental design and seed sowing}

Plots $(1 \mathrm{mx} 1 \mathrm{~m})$ having a vacant inter-plot space of $30 \mathrm{~cm}$ was prepared for carrying out the experimental work. In order to provide moisture for seed germination, each plot was irrigated (2.5litre plot $\left.{ }^{-1}\right)$ one day prior to seeding. Line sowing method was used for seeding and there were three lines in each plot having $30 \mathrm{~cm}$ of inter-line space. Initially, 35-40 seeds were hand-drilled in each of the three lines at a depth $2-3 \mathrm{~cm}$ in each plot on 16 November, 2011. After 28days of seeding, when plants attained rosette stage, thinning was carried out so that 28 plants remained in each row. Thus, a total of 84 plants were maintained in each plot. The experiment was carried out in a randomized complete block design with three replications.

\section{Manure and fertilizer treatments}

Treatments consisted of combinations of three levels of welldecomposed FYM $\left(0,20\right.$ and 30 tons $\left.\mathrm{ha}^{-1}\right)$ and four levels of S $(0$, 10,20 and $\left.30 \mathrm{~kg} \mathrm{ha}^{-1}\right)$. To some of these combinations of FYM and $\mathrm{S}, 60 \mathrm{~kg} \mathrm{ha}^{-1} \mathrm{P} 2 \mathrm{O} 5$ and $100 \mathrm{~kg} \mathrm{ha}^{-1} \mathrm{~N}$ were also added. In all, a total of 15 treatment combinations (T1-T15) including control were tested in the experiment (Table 1). FYM, chiefly composed of cattle dung and urine along with litter and left over material from fodder and containing $0.5 \% \mathrm{~N}, 0.2 \% \mathrm{P} 2 \mathrm{O} 5$ and $0.5 \% \mathrm{~K}_{2} \mathrm{O}$, was applied 30days prior to seeding. $\mathrm{P} 2 \mathrm{O} 5$ was applied as diammonium phosphate (DAP) $(46 \%$ P2O5 and $21 \% \mathrm{~N})$ at the time of seeding through broadcast in selected treatments (T4 to T12), whereas $\mathrm{S}$ was applied as ammonium sulphate $(24 \% \mathrm{~S}$ and $21 \% \mathrm{~N})$ after 28 days of seeding. Nitrogen was provided as urea $(46 \% \mathrm{~N})$ after 34 days of seeding. In order to balance the dose of $\mathrm{N}\left(100 \mathrm{~kg} \mathrm{ha}^{-1}\right)$, amount of urea was adjusted to the treatments that received $\mathrm{N}$ fertilization through DAP and ammonium sulphate. Treatments T13, T14 and T15 received 10, 20 and 30kg S $\mathrm{ha}^{-1}$ respectively, though partial dose of $\mathrm{N}\left(8.8,17.6\right.$ and $26.4 \mathrm{~kg} \mathrm{ha}^{-1}$ in T13, T14 and T15 respectively) was also gone to them through ammonium sulphate (Table 1).

Table I Details of treatment combinations of FYM and inorganic nutrients

\begin{tabular}{lllll}
\hline \multirow{2}{*}{ Treatment } & FYM & Sulphur & $\mathbf{P}_{\mathbf{2}} \mathbf{O}_{\mathbf{5}}$ & Nitrogen \\
\cline { 2 - 5 } & $\left(\right.$ tons ha $\left.^{-1}\right)$ & $\left(\mathrm{kg} \mathrm{ha}^{-1}\right)$ & $\left(\mathrm{kg} \mathrm{ha}^{\prime}\right)$ & $\left(\mathrm{kg} \mathrm{ha}^{-1}\right)$ \\
\hline TI (Control) & 0 & 0 & 0 & 0 \\
T2 & 20 & 0 & 0 & 0 \\
T3 & 30 & 0 & 0 & 0 \\
T4 & 0 & 10 & 60 & 100 \\
T5 & 20 & 10 & 60 & 100 \\
T6 & 30 & 10 & 60 & 100 \\
T7 & 0 & 20 & 60 & 100 \\
T8 & 20 & 20 & 60 & 100 \\
T9 & 30 & 20 & 60 & 100 \\
T10 & 0 & 30 & 60 & 100 \\
TII & 20 & 30 & 60 & 100 \\
T12 & 30 & 30 & 60 & 100 \\
T13 & 0 & 10 & 0 & 8.8 \\
T14 & 0 & 20 & 0 & 17.6 \\
T15 & 0 & 30 & 0 & 26.4 \\
\hline
\end{tabular}

\section{Intercultural operations and management}

After seedling emergence, irrigation (2litres per plot) was carried out daily by water cans until $23^{\text {rd }}$ day of emergence. Thereafter, irrigation with same amount of water was carried out on alternate days until $42^{\text {nd }}$ day and after this period, at every $4^{\text {th }}$ day until pod setting. Weeding was done manually as and when required. Harvesting was carried out after 82 days of seeding (i.e., on 05 February 2012) when $70 \%$ silicles turned light-brown in colour. Harvested biomass was shade dried for four days and threshed by hand.

\section{Data collection}

Data on plant height $(\mathrm{cm})$, number of branches plant ${ }^{-1}$, number of silicles plant ${ }^{-1}$ and seed yield were recorded for 12 plants plot $^{-1}$ (four randomly selected plants in each of the three rows in each plot) at the 
time of harvest. Number of seeds silicle ${ }^{-1}$ was measured by counting number of seeds in five randomly selected silicles on the abovementioned plants (12 plants plot $\left.{ }^{-1}\right)$, for which data on growth and yield parameters was recorded. Thus, a total of 60silicles were sampled in each plot for collecting data on number of seeds silicle ${ }^{-1}$. Data were subjected to analysis of variance (ANOVA) for determination of significance among the treatments.

\section{Seed oil content and fatty acid composition}

Oil content in camelina seeds was determined by solvent extraction method. About 50g of seed of each treatment (except those exhibited very low seed yield) were crushed to fine powder. For oil content determination, the powdered samples of seeds were extracted in Soxhlet apparatus using petroleum ether $\left(60-80^{\circ} \mathrm{C}\right)$ as solvent. The extract was concentrated under vacuum at $65-70^{\circ} \mathrm{C}$, the residual oil was cooled and weighed. Fatty acid composition of seed oil was determined by gas chromatographic method. Preparation of fatty acid methyl esters from camelina seed oil was carried out using AOCS official method Ce 2-66. ${ }^{17}$ Where boron trifluoride in methanol is used as trans methylating agent. The fatty acid methyl esters derived from camelina oil were analyzed by capillary gas chromatography using AOCS official method Ce 1-62. ${ }^{18}$

\section{Results and discussion}

\section{Plant height and number of branches and silicles per plant}

Plant height was recorded between $48.7 \mathrm{~cm}$ (control) and $63.1 \mathrm{~cm}$ (T10) (Table 2). Although variations in plant height were observed among the treatments, not all the treatments were significantly $(\mathrm{P}<0.05)$ different from each other. Addition of $\mathrm{N}\left(100 \mathrm{~kg} \mathrm{ha}^{-1}\right)$ and P2O5 $\left(60 \mathrm{~kg} \mathrm{ha}^{-1}\right)$ to the treatments (T4 to T12) has significantly influenced plant height over control. Improvement in growth of camelina has been observed with nitrogen fertilization $(60-120 \mathrm{~kg}$ ha ${ }^{1}$ ) and a constant dose of $\mathrm{P}$ and $\mathrm{K} .{ }^{19}$ Number of branches plant ${ }^{-1}$ was recorded from 4.5 (control) to $9.4 \mathrm{~cm}$ (T12) (Table 2). Slightly lower number of branches (4.6 to 7.3 branches plant -1) than the present study was reported by Agegnehu and Honermeier. ${ }^{20}$ In camelina, who observed significant increase in number of branches plant ${ }^{-1}$ in presence of $\mathrm{N}, \mathrm{P} 2 \mathrm{O} 5, \mathrm{~K}$ and $\mathrm{CaO}$. Number of silicles plant ${ }^{-1}$ ranged between 60.8 (control) and 222.2 (T12). Addition of N (100kg ha $\left.{ }^{-1}\right)$ and P2O5 $\left(60 \mathrm{~kg} \mathrm{ha}^{-1}\right)$ to the treatments, resulted in significant $(\mathrm{P}<0.05)$ increase in number of silicles plant ${ }^{-1}$. Although addition of $\mathrm{N}$ and $\mathrm{P}$ to the soil has positively influenced plant height and number of branches and silicles, application of $\mathrm{S}$ could neither alone nor in combination with $\mathrm{N}, \mathrm{P} 2 \mathrm{O} 5$ and FYM significantly influence these attributes. Positive and synergistic effects of $\mathrm{N}$ and $\mathrm{S}$ on number of branches in camelina are well documented. ${ }^{14}$ But Sulfur addition had no effect at lower dose of Nitrogen. ${ }^{21,22}$ Perhaps due to this phenomenon, the dose of $\mathrm{N}$ $\left(100 \mathrm{~kg} \mathrm{ha}^{-1}\right)$ applied in the present study was not sufficient enough to get synergize with $\mathrm{S}$ and promote plant growth.

\section{Seed yield and yield attributing traits}

Number of seeds silicle ${ }^{-1}$ was recorded between 11.9 (T6) and 14.1 (T5), though the differences among the treatments were not significant $(\mathrm{P}<0.05)$ (Table 2). Number of seeds silicle ${ }^{-1}$ in the present study broadly fell within the range reported by different researchers in camelina. ${ }^{19,23}$ Crop matured in 82 days after seeding relatively earlier in comparison to the crop maturity period (i.e., 105 to 234days) in camelina as reported by Berti et al. ${ }^{23}$ in their study conducted in cold and temperate Mediterranean climate in Chile. Shorter crop maturity period in the study was perhaps due to the hotter climate of our study site. Seed yield increased significantly $(\mathrm{P}<0.05)$ by addition of $\mathrm{N}\left(100 \mathrm{~kg} \mathrm{ha}^{-1}\right)$ and P2O5 $\left(60 \mathrm{~kg} \mathrm{ha}^{-1}\right)$ to the treatments (T4 to T12). However, lower $\mathrm{N}$ dosage $\left(8.8,17.6\right.$ and $\left.26.4 \mathrm{~kg} \mathrm{ha}^{-1}\right)$ could not affect seed yield (T13 to T15). Nitrogen positively affects number and weight of pods and seed and flowers per plant and thus promote seed yield. ${ }^{14}$ In camelina, increase in seed yield with increased N. ${ }^{20}$ And N, $\mathrm{P}$ and $\mathrm{K} \cdot{ }^{19}$ Fertilization has already been reported. Wide variation in seed yield has been reported ranging from $420 \mathrm{~kg} \mathrm{ha}^{-1}$ to $2314 \mathrm{~kg} \mathrm{ha}^{-1}$ in camelina cultivated at different environments (locations) in Chile. ${ }^{23}$ Although camelina is reported to exhibit adaptability to different climates and soil. ${ }^{10}$ Unfavorable climatic conditions adversely affect its seed yield. ${ }^{19}$ Particularly discussing the patterns of seed yield of camelina cv. Calena in the Indian context, seed yield ranging from 226.7 to $458.9 \mathrm{~kg} \mathrm{ha}^{-1} .{ }^{24}$ And up to $1481 \mathrm{~kg} \mathrm{ha}^{-1} .{ }^{25}$ in open field have been reported in Central Western Himalaya. In view of this, seed yield in the present study was considerable indicating promising potentials of cultivating camelina in hot climate of semi-arid zone. Although Sulfur is reported to increase seed yield in different plants of Brassicaceae family. ${ }^{22,26,27}$ No such effect of Sulfur was observed in the present study. Higher dose of Sulfur (135 $\left.\mathrm{kg} \mathrm{ha}^{-1}\right)$ in comparison to the lower dose $\left(75 \mathrm{~kg} \mathrm{ha}^{-1}\right)$ in presence of a constant dosage of $\mathrm{N}$ have exhibited higher seed yield in camelina. ${ }^{14}$ This suggested that dosages of Sulfur applied in the present study were in low range that could not affect the seed yield although up to $30 \mathrm{~kg} \mathrm{~S} \mathrm{ha}^{-1}$ itself has been found effective in increasing seed yield in mustard. ${ }^{27}$

Table 2 Growth performance, seed yield and oil content of camelina in response to different treatment combinations of FYM and inorganic nutrients

\begin{tabular}{|c|c|c|c|c|c|c|}
\hline Treatments & $\begin{array}{l}\text { Plant height } \\
(\mathrm{cm})^{\mathrm{a}}\end{array}$ & $\begin{array}{l}\text { Number of } \\
\text { branches Plant }^{-1 a}\end{array}$ & $\begin{array}{l}\text { Number of silicles } \\
\text { Plant }^{-1 a}\end{array}$ & $\begin{array}{l}\text { Number of } \\
\text { SEEDS Silicle }\end{array}$ & Seed Yield $\left(\mathrm{g} \mathrm{m}^{2}\right)^{\mathrm{a}}$ & Seed oil content (\%) \\
\hline TI (control) & $48.7 \pm 1.7 d b$ & $4.5 \pm 0.6 e$ & $60.8 \pm 7.4 f$ & $13.3 \pm 0.2 \mathrm{a}$ & $12.8 \pm 1.5 c$ & 31.5 \\
\hline $\mathrm{T} 2$ & $52.9 \pm 1.6 \mathrm{bcd}$ & $4.8 \pm 0.6 \mathrm{e}$ & $78.6 \pm 12.6 \mathrm{def}$ & $13.3 \pm 0.9 \mathrm{a}$ & $19.5 \pm 2.2 \mathrm{c}$ & na \\
\hline T3 & $55.5 \pm 1.8 \mathrm{abcd}$ & $5.5 \pm 0.5 \mathrm{cde}$ & $108.6 \pm 15.8 \mathrm{cdef}$ & $12.4 \pm 0.1 \mathrm{a}$ & $23.5 \pm 3.3 c$ & na \\
\hline $\mathrm{T} 4$ & $59.8 \pm 2.9 \mathrm{abc}$ & $7.4 \pm 0.8 \mathrm{abc}$ & $172.9 \pm 24.4 \mathrm{abc}$ & $13.3 \pm 0.8 \mathrm{a}$ & $48.1 \pm 9.8 b$ & 31.2 \\
\hline T5 & $59.9 \pm 1.2 \mathrm{ab}$ & $7.8 \pm 0.8 \mathrm{abc}$ & $|5| .9 \pm 24.2 \mathrm{abcd}$ & $14.1 \pm 0.6 \mathrm{a}$ & $63.6 \pm 5.5 \mathrm{ab}$ & 29.1 \\
\hline T6 & $59.6 \pm 1.6 a b c$ & $8.9 \pm 1.3 \mathrm{ab}$ & $168.4 \pm 44.5 \mathrm{abc}$ & $11.9 \pm 0.3 \mathrm{a}$ & $66.8 \pm 12.2 \mathrm{ab}$ & 31.7 \\
\hline T7 & $62.9 \pm 1.2 \mathrm{a}$ & $7.7 \pm 0.6 \mathrm{abc}$ & 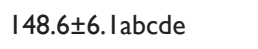 & $13.4 \pm 1.0 \mathrm{a}$ & $71.8 \pm 8.8 \mathrm{a}$ & 31.4 \\
\hline T8 & $60.3 \pm 0.6 \mathrm{ab}$ & $8.6 \pm 0.6 \mathrm{ab}$ & $160.7 \pm 9.2 \mathrm{abc}$ & $12.4 \pm 1.3 \mathrm{a}$ & $70.7 \pm 4.8 a$ & 31.5 \\
\hline
\end{tabular}


Table Continued.

\begin{tabular}{|c|c|c|c|c|c|c|}
\hline Treatments & $\begin{array}{l}\text { Plant height } \\
(\mathrm{cm})^{\mathrm{a}}\end{array}$ & $\begin{array}{l}\text { Number of } \\
\text { branches Plant }^{-1 a}\end{array}$ & $\begin{array}{l}\text { Number of silicles } \\
\text { Plant-la }^{-1}\end{array}$ & $\begin{array}{l}\text { Number of } \\
\text { SEEDS Silicle }\end{array}$ & Seed Yield $\left(\mathrm{g} \mathrm{m}^{2}\right)^{\mathrm{a}}$ & Seed oil content (\%) \\
\hline T9 & $59.3 \pm 2.6 a b c$ & $7.4 \pm 0.7 \mathrm{abc}$ & $143.5 \pm 10.2 \mathrm{bcde}$ & $12.9 \pm 1.0 \mathrm{a}$ & $72.2 \pm 4.1 \mathrm{a}$ & 30.9 \\
\hline TIO & $63.1 \pm 3.8 a$ & $7.5 \pm 0.7 \mathrm{abc}$ & $175.5 \pm 37.6 \mathrm{abc}$ & $13.0 \pm 0.6 \mathrm{a}$ & $65.6 \pm 6.3 \mathrm{ab}$ & 32.5 \\
\hline TII & $57.9 \pm 2.2 \mathrm{abc}$ & $7.2 \pm 0.3 \mathrm{abcd}$ & $193.3 \pm 25.9 \mathrm{ab}$ & $13.3 \pm 0.9 \mathrm{a}$ & $67.4 \pm 5.9 \mathrm{ab}$ & 32.3 \\
\hline TI2 & $58.1 \pm 2.7 \mathrm{abc}$ & $9.4 \pm 0.7 \mathrm{a}$ & $222.2 \pm 40.4 \mathrm{a}$ & $12.8 \pm 0.6 \mathrm{a}$ & $66.3 \pm 7.7 \mathrm{ab}$ & 31.4 \\
\hline TI3 & $53.2 \pm 2.6 \mathrm{bcd}$ & $4.7 \pm 0.6 \mathrm{e}$ & $73.6 \pm 8.7$ ef & $12.2 \pm 1.0 \mathrm{a}$ & $16.7 \pm 1.8 c$ & na \\
\hline TI4 & $52.3 \pm \mathrm{I} . \mathrm{Icd}$ & $5.1 \pm 0.2 \mathrm{de}$ & 108.6 \pm 9.7 cdef & $13.0 \pm 0.7 \mathrm{a}$ & $18.7 \pm 1.9 \mathrm{c}$ & na \\
\hline TI5 & $53.6 \pm 3.5 \mathrm{bcd}$ & $6.7 \pm 0.8 \mathrm{bcde}$ & $105.4 \pm 21.2 \mathrm{cdef}$ & $12.5 \pm 0.3 a$ & $18.7 \pm 3.3 c$ & 29.8 \\
\hline
\end{tabular}

a:Values are means $( \pm$ SEM) of three replicates.

b:Values within each column followed by the same letter did not differ significantly $(P<0.05)$.

na: Seed oil content not analysed.

\section{Seed oil content and fatty acid composition}

Seed oil content of camelina ranged between $29.1 \%$ (T5) and $32.5 \%$ (T10) (Table 2). Seed oil content of the samples of treatments T2, T3, $\mathrm{T} 13$ and T 14 was not analyzed as seed yields were low in them. As such, seed oil content of camelina in the present study fell within the range reported by different researchers across the world. ${ }^{4,9,14}$ Nearly $32 \%$ oil content in camelina cv. Calena has been reported. ${ }^{7}$ Which also corresponded with that of the present study? However, higher range of oil content (35.9 to 38.7\%) in the same cultivar (Calena) of camelina, grown at the temperate zone of Central Western Himalaya has been reported. ${ }^{24}$ Since, adaptability of crop to the environment is reported to cause considerable variations in the seed oil content among different locations. ${ }^{7,9}$ variation in the oil content of cv calena may be attributed to this fact. Results revealed that seed oil content in most of the treatment combinations of FYM, S, N and P2O5 remained either lower or nearly equal to that in control indicating no effect of fertilizers on seed oil content of camelina. Although it is reported that Sulfur positively affects oil content in oilseed crops. ${ }^{26}$ no such trend was observed in the present study as also reported by other workers. ${ }^{14,27}$ Organic fertilizers have been considered as a source of nutrients as well as they can positively influence P-availability in soil. ${ }^{15,16}$ And consequently promote crop production. However, in the present study, FYM could neither influence vegetative growth nor seed yield nor seed oil content of camelina. Oil composition was analyzed only in seed samples of control (T1) in order to assess the patterns of fatty acid profile of seed oil of camelina grown in hot semiarid climate. Results revealed that linolenic (C18:3), linoleic (C18:2), eicosenoic (C20:1) and oleic (C18:1) acids are the principal fatty acid components of camelina seed oil (Table 3). In general, patterns of fatty acid composition of camelina (cv. Calena) oil observed in the present study were almost identical to those reported previously for the same cultivar. ${ }^{9}$ However, concentration of linoleic acid (20.5\%) reported in the present study was higher. On the other hand, linoleic acid conent in camelina oil in the present study was nearly equal to that described in other studies. ${ }^{8}$ Such variations in fatty acid content in camelina oil may be explained by the fact that besides cultivar specific characteristics, environmental conditions also affect fatty acid composition. ${ }^{2,7}$

Table 3 Fatty acid composition of seed oil of camelina grown at hot semi-arid climate

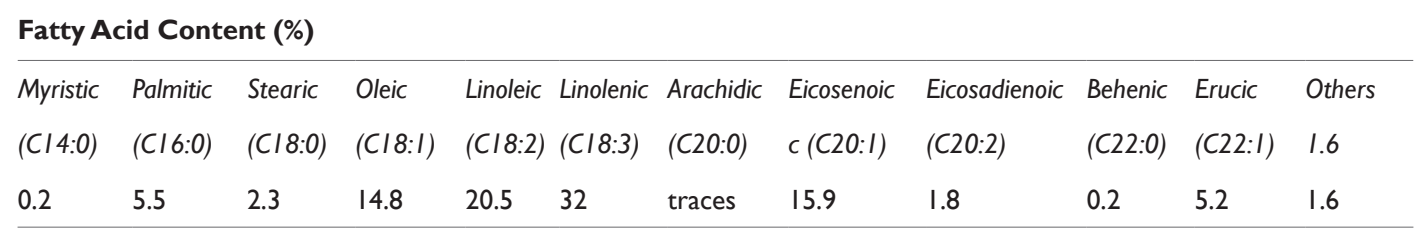

\section{Conclusion}

The study concluded that successful cultivation of camelina can be carried out in degraded lands of hot semi-arid region and considerable seed yield and oil content can be obtained that too by applying relatively lesser nutrient inputs. Application of $\mathrm{N}\left(100 \mathrm{~kg} \mathrm{ha}^{-1}\right)$ and P2O5 (60 $\left.\mathrm{kg} \mathrm{ha}^{-1}\right)$ was found critical for achieving optimal plant growth and seed yield of camelina, whereas S (up to $30 \mathrm{~kg} \mathrm{ha}^{-1}$ ) and FYM (up to 30tons ha ${ }^{-1}$ ) fertilization could neither influence plant growth nor seed yield nor oil content. Camelina seed oil content remained unaffected by tested dosages of both organic manure and mineral nutrients (N, P2O5, and S). Fatty acid composition of camelina seed oil was comparable to those described in the previous reports. Since, this is the first study assessing the agronomic attributes of camelina in the degraded land of hot semi-arid zone of India; therefore, there is a wide scope for enhancing the seed yield and oil content of camelina by optimizing its water and nutrient requirements and standardizing planting time and density for the region.

\section{Acknowledgements}

Dr. J. Vollmann, BOKU-University of Natural Resources and Applied Life Sciences, Vienna, Austria is gratefully acknowledged for providing the nucleus seed of camelina cv. Calena. Thanks to Director, NBPGR, New Delhi for providing necessary support in importing camelina seed. Thanks are also due to the technical and supporting staff of DIBER Project Site, Ahmednagar for their assistance during the course of study.

\section{Conflict of interest}

The author declares no conflict of interest. 


\section{References}

1. Putnam DH, Budin JT, Field LA, et al. Camelina: A promising low input oilseed. In: J Janick, et al. editors. New Crops, USA: Wiley; 1993. p. 314-322.

2. Budin JT, Breene WM, Putnam DH. Some compositional properties of camelina (Camelina sativa L. Crantz) seeds and oils. Journal of the American Oil Chemists' Society. 1995;72(3):309-315.

3. Fröhlich A, Rice B. Evaluation of Camelina sativa oil as a feedstock for biodiesel production. Ind Crops Prod. 2005;21:25-31.

4. Vollmann J, Grausgruber H, Stift G, et al. Genetic diversity in camelina germplasm as revealed by seed quality characteristics and RAPD polymorphism. Plant Breed. 2005;124(5):446-453.

5. Moser BR. Camelina (Camelina sativa L.) oil as a biofuels feedstock: Golden opportunity or false hope? Lipid Technol. 2010;22(12):270-273.

6. Moser BR, Vaughn SF. Evaluation of alkyl esters from Camelina sativa oil as biodiesel and as blend components in ultra low-sulfur diesel fuel. Bioresour Technol. 2010;101(2):646-653.

7. Pilgeram AL, Sands DC, Boss D, et al. Camelina sativa, a Montana omega -3 and fuel crop, in:J anick J, et al. editors. Issues in new crops and new uses. USA: ASHS Press; 2007. p. 129-131.

8. Pavlista AD, Santra DK, Isbell TA, et al. Adaptability of irrigated spring canola oil production to the US High Plains. Ind Crops Prod. 2011;33:165-169.

9. Vollmann J, Moritz T, Kargl C, et al. Agronomic evaluation of camelina genotypes selected for seed quality characteristics. Ind Crops Prod. 2007;26:270-277.

10. Zubr J. Oil-seed crop: Camelina sativa. Ind Crops Prod. 1997;6:113119.

11. Agarwal A, Pant T, Ahmed Z. Camelina sativa: a new crop with biofuel potential introduced in India. Curr Sci. 2010;99(9):1194-1195.

12. Ahmad A, Abdin MZ. Effect of sulphur application on lipid, RNA and fatty acid content in developing seeds of rapeseed (Brassica campestris L.). Plant Sci. 2000;152:71-76.

13. Schnug E, Haneklaus S, Murphy D. Impact of sulphur fertilization on fertilizer nitrogen efficiency. Sulphur in Agric. 1993;17:8-12.

14. Losak T, Hlusek J, Martinec J, et al. Effect of combined nitrogen and sulphur fertilization on yield and qualitative parameters of Camelina sativa [L.] Crtz. (false flax). Acta Agric Scandi Section B-Soil and Plant Science. 2011;61(4):313-321.
15. Richardson AE, George TS, Hens M, et al. Utilization of soil organic phosphorus by higher plants in: Turner BL, et al. editors. Organic phosphorus in the environment. UK: CABI Publishing; 2005. p. 165-184.

16. Eichler-Lobermann B, Kohne S, Kowalski B, et al. Effect of catch cropping on phosphorus bioavailability in comparison to organic and inorganic fertilization. J Plant Nutr. 2008;3(4):659-676.

17. AOCS. AOCS Official Method Ce 2-66, Preparation of methyl esters of fatty acids, sampling and analysis of commercial oils and fats, reapproved; 1997.

18. AOCS. AOCS Official Method Ce 1-62, Fatty acid composition by gas chromatography, sampling and analysis of commercial oils and fats, reapproved; 1997.

19. Koncius D, Karcauskiene D. The effect of nitrogen fertilizers, sowing time and seed rate on the productivity of Camelina sativa. Zemdirbyste Agriculture. 2010;97(4):37-46.

20. Agegnehu M, Honermeier B. Effects of seeding rates and nitrogen fertilization on seed yield, seed quality and yield components of false flax (Camelina sativa Crtz.). Die Bodenkultur. 1997;48(1):15-21.

21. Salvagiotti F, Castellarin JM, Miralles DJ, et al. Sulfur fertilization improves nitrogen use efficiency in wheat by increasing nitrogen uptake. Field Crops Res. 2009;113:170-177.

22. McGrath SP, Zhao FJ. Sulphur uptake, yiel d responses and interactions between nitrogen and sulphur in winter oilseed rape (Brassica napus). $J$ Agric Sci. 1996;126:53-62.

23. Berti M, Wilckens R, Fischer S, et al. Seeding date influence on camelina seed yield, yield components, and oil content in Chile. Ind Crops Prod. 2011;34:1358-1365.

24. Kumari A, Mohsin M, Arya MC, et al. Effect of spacing on Camelina sativa: a new biofuel crop in India. The Bioscan. 2012;7:575-577.

25. Agarwal A, Arya MC, Ahmed Z. Influence of sowing time, environment and spacing on seed yield and oil recovery in camelina (Camelina sativa). Indian J Agri c Sci. 2013;83(7):724-727.

26. Grant C, Clayton G, Johnston A. Sulphur fertilizer and tillage effects on canola seed quality in the Black soil zone of western Canada. Can J Plant Sci. 2003;83:745-758.

27. Chandel RS, Sudhakar PC, Singh K. Direct and residual effect of sulphur on Indian mustard (Brassica juncea) in rice (Oryza sativa) -Indian mustard cropping system. Indian J Agric Sci. 2002;8(2):155-159. 